\title{
Mineralization and Metabolism of the Herbicide Isouron in Aqueous Environment
}

\author{
Yei-Shung Wang, Hsien-Shiow TsaI, Yung-Ho Su* \\ and Yuh-Lin CHEN \\ Department of Agricultural Chemistry, National Taiwan University, \\ Taipei, Taiwan, Republic of China \\ *Department of Food Industry, National Chai-Yi Institute of Agriculture, \\ Chai-Yi, Taiwan, Republic of China
}

(Received June 29, 1990)

\begin{abstract}
The herbicide isouron [3-(5-tert-butyl-3-isoxazolyl)-1,1-dimethylurea] was mineralized to 31 and $25 \%$ in sewage samples at 0.01 and $0.1 \mathrm{ppm}$, respectively, but only $7 \%$ was mineralized in river-water samples in a 120-day period. Although most of the radioactivity remained, only 66 to $68 \%$ of the initial isouron was found in the river-water samples. Data suggest that isouron was converted mainly to organic compounds, presumably by metabolism. Mineralization occurred in microbial environments prevailing in the seawage. A partial pathway involved in the microbial degradation of isouron in the aqueous environments is proposed. Metabolites, 3-(5-tert-butyl-3-isoxazolyl)-1-methyl-1-formylurea and $N$-[5-(1,1dimethyl-2-hydroxyethyl)-3-isoxazolyl]carbamic acid were identified in the sewage samples, these two compounds were not previously found among metabolic products of isouron in soils.
\end{abstract}

\section{INTRODUCTION}

Recent evidence indicates that the mineralization rate of a chemical at high concentrations may not predict what takes place at low concentrations. Isopropyl n-phenylcarbamate (IPC) may be mineralized at one concentration, but apparently metabolized, or at least converted in a high extent to organic products, at another concentration. ${ }^{1)}$ Wang et al. ${ }^{2)}$ have found no evidence for metabolism of diuron [3-(3,4-dichlorophenyl)-1,1-dimethylurea] and linuron [3-(3,4-dichlorophenyl)-1-methoxy-1methylurea] at a high level $(2.0 \mathrm{mg} / \mathrm{l})$, but have noticed a significant amount of an unknown chemical was produced by diuron of low level $(0.5 \mu \mathrm{g} / l)$. Concentration may be a significant factor affecting mineralization of a compound. Boethling \& Alexander ${ }^{3}$ ) have reported that more than $60 \%$ of 2,4-dichlorophenoxyacetic acid (2,4-D) was mineralized within 6 days when initial concentrations were $22 \mu \mathrm{g} / \mathrm{ml}$ and
$0.2 \mu \mathrm{g} / \mathrm{ml}$, but less than $10 \%$ was mineralized within 8 days at initial levels of $2.2 \mathrm{ng} / \mathrm{ml}$ and $22 \mathrm{pg} / \mathrm{ml}$. On the other hand, Subba-Rao et al. ${ }^{4)}$ have reported that 2,4-D was not mineralized at a concentration of $203 \mathrm{ng} / \mathrm{ml}$ in a lake water, but more than $40 \%$ was mineralized at levels below $5 \mathrm{ng} / \mathrm{ml}$ in 30 days. Rubin et al. ${ }^{5)}$ have reported the mineralization of more than $94 \%$ of aniline, phenol, benzylamine and 2,4-D at low concentrations and have suggested that organic compounds may be mineralized without incorporating carbon into cellular components.

The present study was designed to evaluate the mineralization and metabolism of the herbicide isouron at various concentrations in aqueous environments.

\section{MATERIALS AND METHODS}

\section{Chemicals}

Pure isouron $\left(\mathbf{I}, \mathrm{mp} 117-118^{\circ} \mathrm{C}\right),{ }^{14} \mathrm{C}$-isouron labeled at position 5 of the isoxazole ring 
Table $1 \quad R f$ values of isouron and authentic compounds with two developing solvent systems.

\begin{tabular}{|c|c|c|}
\hline \multirow[b]{2}{*}{ Compound } & \multicolumn{2}{|c|}{$R f$ value } \\
\hline & $\begin{array}{l}\mathrm{CHCl}_{3}: \\
\mathrm{MeOH} \\
=9: 1\end{array}$ & $\begin{array}{l}\text { Ethyl } \\
\text { ether }\end{array}$ \\
\hline $\begin{array}{l}\text { 3-(5-tert-Butyl-3-isoxazolyl)- } \\
\text { 1,1-dimethylurea } \\
\text { (I, Isouron) }\end{array}$ & 0.74 & 0.54 \\
\hline $\begin{array}{l}\text { 3-(5-tert-Butyl-3-isoxazoly])- } \\
\text { 1-methyl-1-formylurea } \\
\text { (II) }\end{array}$ & 0.79 & 0.87 \\
\hline $\begin{array}{l}\text { 3-(5-tert-Butyl-3-isoxazolyl)- } \\
\text { 1-methylurea (III) }\end{array}$ & 0.58 & 0.53 \\
\hline $\begin{array}{l}\text { 3-(5-tert-Butyl-3-isoxazolyl)- } \\
\text { urea (IV) }\end{array}$ & 0.40 & 0.47 \\
\hline $\begin{array}{l}\text { 3-Amino-5-tert-butylisoxazole } \\
\text { (V) }\end{array}$ & 0.55 & 0.63 \\
\hline $\begin{array}{l}\text { 3-[5-(1,1-Dimethyl-2-hydro- } \\
\text { xyethyl)-3-isoxazolyl]-1,1- } \\
\text { dimethylurea (VI) }\end{array}$ & 0.39 & 0.24 \\
\hline $\begin{array}{l}\text { 3-[5-(1,1-Dimethyl-2-hydro- } \\
\text { xyethyl)-3-isoxazolyl]-1- } \\
\text { methylurea (VII) }\end{array}$ & 0.29 & 0.27 \\
\hline $\begin{array}{l}\text { 3-[5-(1,1-Dimethyl-2-hydro- } \\
\text { xyethyl-(3-isoxazolyl]urea }\end{array}$ & 0.15 & 0.20 \\
\hline
\end{tabular}

(specific activity, $8.28 \mathrm{mCi} / \mathrm{mmol}$ ) and the authentic compounds of isouron derivatives were provided by Shionogi \& Co., Ltd., Osaka, Japan. The purity of the labeled compound exceeded $99 \%$ as determined by TLC. The authentic compounds were 3-(5-tert-butyl-3isoxazolyl)-1-methyl-1-formylurea (II, mp 99$\left.100^{\circ} \mathrm{C}\right)$, 3-(5-tert-butyl-3-isoxazolyl)-1-methylurea (III, $\left.\mathrm{mp} 189.5-190.5^{\circ} \mathrm{C}\right)$, 3-(5-tert-butyl3-isoxazolyl)urea $\left(\mathbf{I V}, \mathrm{mp} 181-182^{\circ} \mathrm{C}\right), 3$-amino5-tert-butylisoxazole (V, mp $\left.110-111^{\circ} \mathrm{C}\right), 3-[5-$ (1,1-dimethyl-2-hydroxyethyl) - 3 - isoxazolyl]1,1-dimethylurea (VI, mp $147-148^{\circ} \mathrm{C}$ ), 3-[5(1,1-dimethyl-2-hydroxyethyl) - 3-isoxazolyl]1-methylurea (VII, mp $155.5-157^{\circ} \mathrm{C}$ ) and 3-[5-(1,1-dimethyl-2-hydroxyethyl) - 3-isoxazolyl]urea $\left(\mathrm{mp} 151-153^{\circ} \mathrm{C}\right)$. Solvents of the highest purity commercially available were used without further purification. The $R f$ values of the authentic compounds on thinlayer chromatograms are shown in Table 1.

\section{Samples}

Samples of fresh river water were taken in
July 1985 from the Ta-Chia River at the entrance of Shi-Kung Dam, Ta-Chia, Taichung ( $\mathrm{pH}$ 8.1). Sewage was obtained in November 1985 from the settling tanks of Min-Sheng Wastewater Treatment Plant, Taipei $(\mathrm{pH}$ 7.25). The dissolved organic nitrogen and the total phosphorus content were 0.03 and 0.053 $\mu \mathrm{g} / \mathrm{ml}$ for the river water, and 6.4 and 6.8 $\mu \mathrm{g} / \mathrm{ml}$ for the sewage, respectively. Riverwater and sewage samples were passed through a glass micro fiber filter paper (Whatman GF/A, Whatman Limited, England) to remove particulate matter.

\section{Mineralization of Isouron in Aqueous Solution}

Isouron was added to freshly sampled and filtered river water or sewage $(400 \mathrm{ml}$ in $1-l$ Erlenmeyer flasks). Tests were conducted at three concentrations. Unlabeled isouron at $0.01,0.1$ or $1.0 \mathrm{ppm}$, in addition of the labeled chemical at $500 \mathrm{dpm} / \mathrm{ml}$, was added to a flask. The flasks were stoppered with foam plugs and cultured with shaking $(100 \mathrm{rpm})$ in the dark at $30^{\circ} \mathrm{C}$. Each test was conducted in triplicate.

To determine mineralization rates, 5-ml portions of samples were removed at regular intervals. The liquid was acidified with conc. $\mathrm{H}_{2} \mathrm{SO}_{4}$ to $\mathrm{pH} 2$ and bubbled with air to remove $\left.\mathrm{CO}_{2}{ }^{4}\right)$ One milliliter of the treated sample was taken and placed in 20-ml glass scintillation vials, and $6.0 \mathrm{ml}$ of Tritosol (Scintillation Cocktail based on Triton X-100) ${ }^{6}$ was added. The radioactivity of the samples was measured for 10 min with a Beckman LS-230 liquid scintillation system.

\section{Separation and Identification of Isouron and Its Metabolites}

For analysis of metabolites, $20-\mathrm{ml}$ portions of samples were taken at a designed period, extracted three times with $20 \mathrm{ml}$ of the mixed solvent of benzene-ethyl acetate $(3: 1, \mathrm{v} / \mathrm{v})$. The extracts were pooled, concentrated and then dissolved with a small volume of benzeneethyl acetate. The recollected extracts were separated by performing thin-layer chromatographic analysis with Silica Gel $60 \mathrm{~F}_{254}$ precoated plates $(0.25 \mathrm{~mm}$ thick, E. Merck., Germany) with $\mathrm{CHCl}_{3}-\mathrm{MeOH}(9: 1, \mathrm{v} / \mathrm{v})$ as a developing solvent. A mixed solution was 
prepared by adding an equal amount of each authentic compound in acetone, and this solution was applied side by side with the samples on TLC plate. The separated compounds were radioautographed as described in section 5. Silica gel was scraped off the plates separately according to the position of each compound on the autoradiogram, and placed in scintillation vials each containing $6.0 \mathrm{ml}$ of Tritosol for radioactivity measurements.

\section{Experiments for Identification of Isouron} and Its Metabolites by Co-Chromatography

Isouron-added sewage samples were incubated in the dark with forced aeration. On days 35, 75 and 120 a sample was taken, extracted and placed on the thin-layer plate with authentic compounds. Two-dimensional thin-layer chromatographic analysis was carried out with $\mathrm{CHCl}_{3}-\mathrm{MeOH}(9: 1, \mathrm{v} / \mathrm{v})$ and ether as developing solvent system for the first and second dimension, respectively. Radioautography was prepared by using Agfa-Gevaert Curix RPI $\mathrm{X}$-ray film $(8 \times 10$ inch) with Kodak Developer D-19 and Kodak Fixing Bath F-5. Compounds on the thin-layer plate were detected by spraying a solution of $0.1 \%$ of 4-dimethylaminocinnamaldehyde in ethanol-conc. $\mathrm{HCl}$ $(4: 1, \mathrm{v} / \mathrm{v})$ mixture.

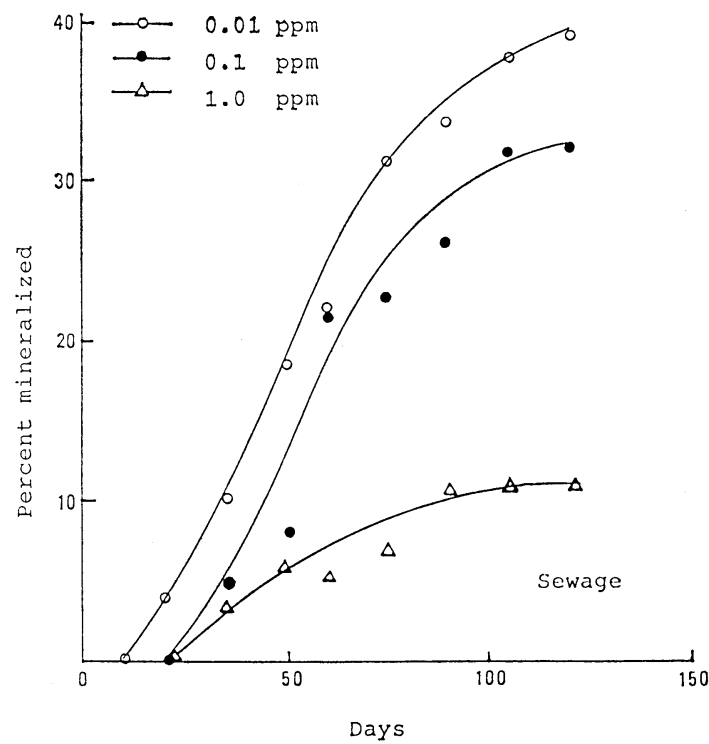

6. Sample Preparation for Identification by Mass Spectrometry

For identification by mass spectrometry, $10 \mathrm{l}$ of sewage sample initially containing $10 \mu \mathrm{g} / \mathrm{ml}$ of isouron in a 20- $l$ glass bottle was incubated at $30^{\circ} \mathrm{C}$ in the dark with forced aeration. After incubated for 120 days, the sample was extracted three times with benzene-ethyl acetate (3: 1). The extract was dried over anhydrous $\mathrm{Na}_{2} \mathrm{SO}_{4}$ and concentrated in a rotary evaporator. The samples were then separated by twodimensional TLC and the separated compounds were identified by autoradiography and collected for mass spectrometry (Jeol JMS-D-300 Mass Spectrometer).

\section{RESULTS AND DISCUSSION}

Mineralization of isouron in river-water and sewage samples is shown in Fig. 1. In river water samples containing $0.1-$ and $0.01-\mathrm{ppm}$ isouron, mineralization occurred after 35 days. The percentage of radioactive organic compounds mineralized was less than $7 \%$ on day 120. At a higher concentration (1 ppm), mineralization was not detected in the riverwater samples on day 75 , but $4 \%$ of isouron was found to be mineralized on day 120 . In sewage samples containing $0.01-, 0.1-$ and 1.0 ppm isouron, 31,25 and $9 \%$ of the compound

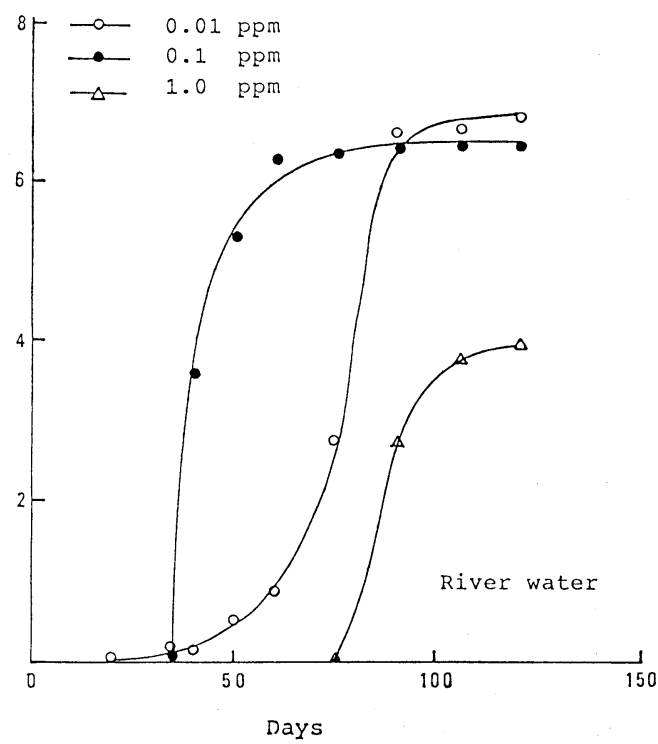

Fig. 1 Mineralization of isouron in sewage and river water at different concentrations. 
Table 2 Distribution of radioactivity in the metabolites of isouron from sewage.

\begin{tabular}{|c|c|c|c|c|c|c|c|}
\hline \multirow{2}{*}{$\begin{array}{c}\text { Isouron } \\
\text { concentration } \\
(\mathrm{ppm})\end{array}$} & \multirow{2}{*}{$\begin{array}{l}\text { Days of } \\
\text { incubation }\end{array}$} & \multicolumn{5}{|c|}{$\begin{array}{c}\text { Distribution of initial radioactivity (\%) } \\
\text { at the following } R f \text { values }\end{array}$} & \multirow{2}{*}{$\begin{array}{l}\text { Radioactivity } \\
\text { remaining } \\
\text { - in sewage } \\
(\%)^{\text {a) }}\end{array}$} \\
\hline & & $1.0-0.77$ & $0.77-0.65$ & $0.65-0.50$ & $0.50-0.35$ & $0.35-0.0$ & \\
\hline \multirow[t]{6}{*}{1.0} & 0 & 0 & 98.80 & 1.20 & 0 & 0 & 100 \\
\hline & 35 & 0.86 & 75.10 & 16.66 & 3.70 & 0.98 & 97.3 \\
\hline & 50 & 1.59 & 73.22 & 16.26 & 3.39 & 0.93 & 95.4 \\
\hline & 75 & 3.12 & 68.56 & 17.69 & 3.90 & 1.43 & 94.7 \\
\hline & 105 & 4.13 & 62.64 & 18.53 & 4.01 & 2.09 & 91.4 \\
\hline & 120 & 7.61 & 56.51 & 17.34 & 5.78 & 4.15 & 91.4 \\
\hline \multirow[t]{6}{*}{0.1} & 0 & 0 & 99.10 & 0.80 & 0.09 & 0 & 100 \\
\hline & 35 & 1.32 & 71.75 & 18.53 & 3.61 & 0.89 & 96.1 \\
\hline & 50 & 1.40 & 70.06 & 18.15 & 3.28 & 0.91 & 93.8 \\
\hline & 75 & 2.46 & 59.75 & 14.94 & 3.19 & 1.56 & 81.9 \\
\hline & 105 & 2.88 & 52.78 & 14.48 & 2.96 & 1.60 & 74.7 \\
\hline & 120 & 3.66 & 51.26 & 14.76 & 3.35 & 1.47 & 74.5 \\
\hline \multirow[t]{6}{*}{0.01} & 0 & 0 & 97.80 & 2.20 & 0 & 0 & 100 \\
\hline & 35 & 2.22 & 63.36 & 18.61 & 5.37 & 2.44 & 92.0 \\
\hline & 50 & 2.30 & 57.82 & 17.50 & 5.11 & 2.36 & 85.1 \\
\hline & 75 & 3.14 & 51.41 & 14.36 & 3.66 & 2.52 & 75.1 \\
\hline & 105 & 5.78 & 40.57 & 14.55 & 5.87 & 3.22 & 70.0 \\
\hline & 120 & 7.39 & 38.09 & 13.09 & 5.70 & 4.63 & 68.7 \\
\hline
\end{tabular}

a) Radioactivity in $1.0-\mathrm{ml}$ portions of unextracted sewage samples.

had been mineralized, respectively, on day 120 .

Within 120 days, more than $30 \%$ of isouron was mineralized in sewage samples to which the compound had been initially added at 0.01 $\mathrm{ppm}$, but for samples containing 1.0-ppm isouron, the figure was less than $10 \%$. The experiment was aimed to determine whether the chemical at higher levels was converted to organic products without transforming to $\mathrm{CO}_{2}$. The metabolites of isouron were analyzed and the results are summarized in Table 2 . Compounds with $R f$ values of 1.0 to 0.77 and 0.77 to 0.65 were 3-(5-tert-butyl-3-isoxazolyl)-1methyl-1-formylurea (II) and isouron, respectively. The band at $R f 0.65$ to 0.50 contained 3-(5-tert-butyl-3-isoxazolyl)-1-methylurea (III) and 3-amino-5-tert-butylisoxazole (V). The band at $R f 0.50$ to 0.35 contained 3-(5-tertbutyl-3-isoxazolyl)urea (IV) and 3-[5-(1,1-dimethyl-2-hydroxyethyl) - 3-isoxazolyl]-1,1-dimethylurea (VI), and that at $R f 0.35$ to 0 implicated 3-[5-(1,1-dimethyl-2-hydroxyethyl)3-isoxazolyl]-1-methylurea (VII) and 3-[5-(1,1dimethyl-2-hydroxyethyl)-3-isoxazolyl]urea.

Formation of products during the decom- position of isouron in sewage samples is shown in Table 2. The extent of mineralization is evidenced by the loss of radioactive carbon from samples. In sewage samples initially receiving 1.0-, $0.1-$ and $0.01-\mathrm{ppm}$ isouron, the radioactivity corresponding to isouron declined to $56.5,51.3$ and $38.1 \%$ of its initial value after 120 days, respectively; this indicate that at least $43.5,48.7$ and $61.9 \%$ of isouron was degraded. During the incubation, polar products were formed, and some of them were further degraded. Although mineralization occurred to a considerable extent at these three concentrations, organic products were also generated; some of them appeared to be not easily converted.

In river-water samples receiving $1.0 \mathrm{ppm}$ isouron, decline of total radioactivity was not evident on day 75 . Suggesting the absence of mineralization before this time (Table 3). However, the radioactivity recovered at the spot corresponding to isouron declined from $98.6 \%$ on day 0 to $77.2 \%$ on day 75 . Ozaki et $a{ }^{7)}{ }^{7)}$ have reported that isouron was rapidly metabolized in soils under anaerobic condition 
Table 3 Distribution of radioactivity in the metabolites of isouron from river water.

\begin{tabular}{|c|c|c|c|c|c|c|c|}
\hline \multirow{2}{*}{$\begin{array}{l}\text { Isouron } \\
\text { concentration } \\
(\text { ppm })\end{array}$} & \multirow{2}{*}{$\begin{array}{l}\text { Days of } \\
\text { incubation }\end{array}$} & \multicolumn{5}{|c|}{$\begin{array}{l}\text { Distribution of initial radioactivity (\%) } \\
\text { at the following } R f \text { values }\end{array}$} & \multirow{2}{*}{$\begin{array}{l}\text { Radioactivity } \\
\text { remaining in } \\
\text { - river water } \\
(\%)^{a)}\end{array}$} \\
\hline & & $1.0-0.77$ & $0.77-0.65$ & $0.65-0.50$ & $0.50-0.35$ & $0.35-0.0$ & \\
\hline \multirow[t]{6}{*}{1.0} & 0 & 0 & 98.62 & 1.38 & 0 & 0 & 100 \\
\hline & 35 & 1.55 & 81.82 & 13.13 & 2.56 & 0.93 & 100 \\
\hline & 50 & 0.95 & 80.99 & 14.52 & 2.69 & 0.85 & 100 \\
\hline & 75 & 2.67 & 77.19 & 15.06 & 3.65 & 1.43 & 100 \\
\hline & 106 & 3.52 & 72.77 & 15.26 & 3.14 & 1.55 & 96.24 \\
\hline & 120 & 5.56 & 68.07 & 15.94 & 4.29 & 2.13 & 96.00 \\
\hline \multirow[t]{6}{*}{0.1} & 0 & 0 & 98.80 & 1.10 & 0.08 & 0 & 100 \\
\hline & 35 & 1.04 & 81.65 & 14.43 & 2.31 & 0.57 & 100 \\
\hline & 50 & 0.99 & 77.48 & 13.36 & 2.34 & 0.52 & 94.70 \\
\hline & 75 & 2.18 & 73.34 & 14.84 & 2.23 & 1.09 & 93.69 \\
\hline & 106 & 2.62 & 69.21 & 15.49 & 3.80 & 2.48 & 93.60 \\
\hline & 120 & 4.22 & 67.80 & 17.68 & 2.65 & 1.18 & 93.55 \\
\hline \multirow[t]{6}{*}{0.01} & 0 & 0 & 96.81 & 3.19 & 0 & 0 & 100 \\
\hline & 35 & 2.48 & 78.30 & 13.67 & 3.94 & 1.40 & 99.80 \\
\hline & 50 & 1.59 & 77.22 & 14.58 & 3.12 & 2.98 & 99.50 \\
\hline & 75 & 1.49 & 73.42 & 15.80 & 4.35 & 2.18 & 97.26 \\
\hline & 106 & 1.20 & 70.34 & 16.29 & 3.47 & 2.04 & 93.35 \\
\hline & 120 & 1.99 & 66.54 & 16.61 & 5.32 & 2.75 & 93.22 \\
\hline
\end{tabular}

a) Radioactivity in $1.0-\mathrm{ml}$ portions of unextracted river-water samples.

and that the half-life was 1 to 2 months. They have also reported $^{8}$ that isouron was hardly degraded in loamy sand and light clay soil.

Change of degradation products was also observed by autoradiography. When isouron was incubated in sewage samples for 35 days, compounds II and $\mathbf{V}$ were found. The metabolite II disappeared and an unknown metabolite $\mathbf{X}$ appeared after 75 days; metabolite $\mathbf{X}$ disappeared but metabolite IX appeared up to 120 days. Compound III was a major metabolite. Metabolites III, IV and $\mathbf{V}$ were fairly stable and increased as time elapsed.

Metabolites II to VII were identified by comparison of the mass spectra with those of authentic compounds. The results agreed with those proposed from the thin-layer chromatographic analysis. Metabolite VIII was found in the 120-day incubation sample. Although it appeared close to sample origin on the TLC plate with both two developing solvent systems, it was not identical with an authentic compound 3-[5-(1,1-dimethyl-2-hydroxyethyl)-3isoxazolyl] urea [MS $m / e: 199\left(\mathrm{M}^{+}, 47 \%\right), 168\left(\mathrm{M}^{+}\right.$ $\left.-\mathrm{CH}_{2} \mathrm{OH}, 100 \%\right), 156\left(\mathrm{M}^{+}-\mathrm{CONH}_{2}+1,37 \%\right)$,
$125\left(\mathrm{M}^{+}-\mathrm{CH}_{2} \mathrm{OH}-\mathrm{CONH}_{2}+1,92 \%\right)$ and 111 $\left.\left(\mathrm{M}^{+}-\mathrm{NHCONH}_{2}+1-\mathrm{CH}_{2} \mathrm{OH}+1,31 \%\right)\right]$. The mass spectrum of metabolite VIII gave MS m/e: $200\left(\mathrm{M}^{+}, 6 \%\right), 169\left(\mathrm{M}^{+}-\mathrm{CH}_{2} \mathrm{OH}, 100 \%\right)$, $166\left(\mathrm{M}^{+}-2(\mathrm{OH}), 82 \%\right), 156\left(\mathrm{M}^{+}-\mathrm{COOH}+1\right.$, $29 \%), 137\left(\mathrm{M}^{+}-\mathrm{COOH}-\mathrm{OH}, 67 \%\right), 125\left(\mathrm{M}^{+}\right.$ $\left.-\mathrm{CH}_{2} \mathrm{OH}-\mathrm{COOH}+1, \quad 18 \%\right)$ and $111\left(\mathrm{M}^{+}\right.$ $-\mathrm{NHCOOH}+1-\mathrm{CH}_{2} \mathrm{OH}+1, \quad 12 \%$ ). The metabolite VIII was identified by this mass spectrum as $N$-[5-(1,1-dimethyl-2-hydroxyethyl)-3-isoxazolyl] carbamic acid. Metabolite IX gave MS $m / e: 271\left(\mathrm{M}^{+}\right), 211,167,140,128$, 111 and 97 , and metabolite $\mathbf{X}$ gave MS m/e: $340\left(\mathrm{M}^{+}\right), 316,284,256$, and 227 . The two unknown metabolites were proposed as polymers of the degradation products of isouron, because the major fragments of these two compounds were the same as that of isouron or its metabolites.

From the above results, a partial pathway involved in the microbial degradation of herbicide isouron in the aqueous environments is proposed (Fig. 2). Compounds II and VIII were detected in the aqueous solutions in this study, although, they were not found when 

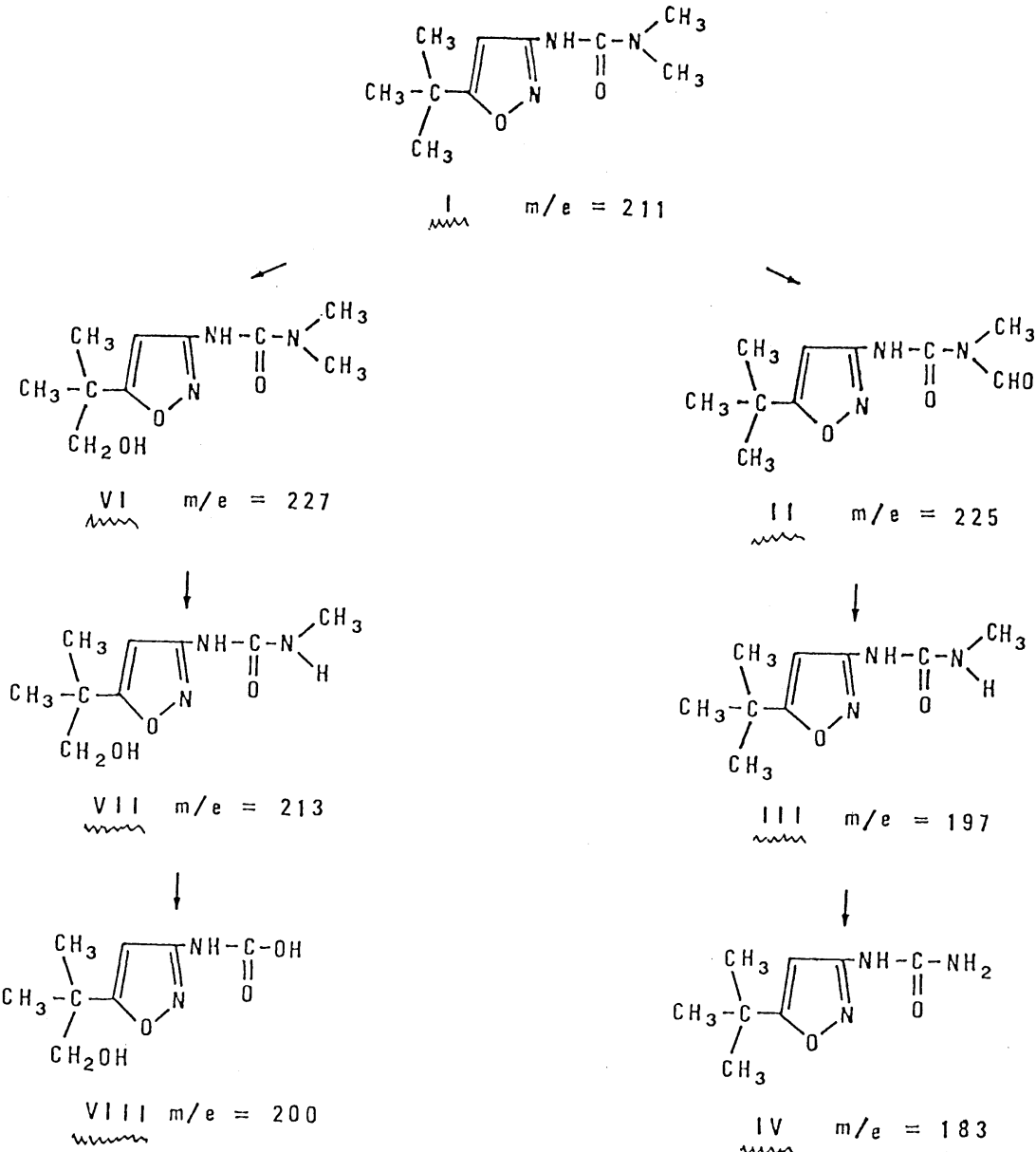

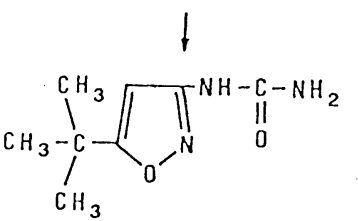

IV $\mathrm{m} / \mathrm{e}=183$

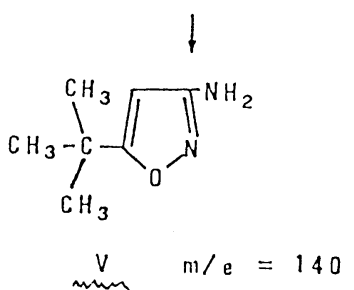

Fig. 2 Partial pathways involved in the biodegradation of isouron in an aqueous environment.

isouron degraded in soil in our previous study. ${ }^{9}$ Ozaki \& Kuwatsuka have reported that these two metabolites were not detected when isouron was degraded by bacterium Pseudomonas putida. ${ }^{10)}$ They have also emphasized that isouron was degraded reductively to 1-(1-amino-4,4-dimethyl-3-oxo-1pentenyl)-3,3-dimethylurea by Pseudomonas putida. Compound II was not found among metabolites produced when isouron was degraded by Rhizoctonia solani. ${ }^{11,12)}$ However, photolysis of the urea herbicide monuron, which degraded to its formyl derivative in aqueous solution, was reported by Crosby \& Tang ${ }^{13)}$ and Tanaka et al. ${ }^{14)}$ 3-[5-(1,1-Dimethyl-2-hydroxyethyl)-3-isoxazolyl] urea was found in soil but not in the aqueous solutions in this study. 


\section{ACKNOWLEDGMENTS}

The authors wish to express their sincere thanks to Shionogi \& Co., Ltd., Osaka, Japan, for providing pure and ${ }^{14} \mathrm{C}$-labeled isouron, and authentic samples of the derivatives of isouron for this experiment. Appreciation is due to Prof. Yu-Yuan Yeh, Radioisotope Laboratory, Department of Horticulture, National Taiwan University, for his technical guidance in the measurement of radioactivity. This work was supported by the National Science Council of the Republic of China, No. NSC 75-0409-B002-31.

\section{REFERENCES}

1) Y. S. Wang, R. V. Subba-Rao \& M. Alexander: Appl. Environ. Microbiol. 47, 1195 (1984)

2) Y. S. Wang, E. L. Madsen \& M. Alexander: J. Agric. Food Chem. 33, 495 (1985)

3) R. S. Boethling \& M. Alexander: Appl. Environ. Microbiol. 37, 1211 (1979)

4) R. V. Subba-Rao, H. E. Rubin \& M. Alexander: Appl. Environ. Microbiol. 43, 1139 (1982)

5) H. E. Rubin, R. V. Subba-Rao \& M. Alexander: Appl. Environ. Microbiol. 43, 1133 (1982)

6) U. Fricke: Anal. Biochem. 63, 555 (1975)

7) M. Ozaki, Y. Tanaka \& S. Kuwatsuka: J. Pesticide Sci. 11, 409 (1986)

8) M. Ozaki, Y. Tanaka \& S. Kuwatsuka: J. Pesticide Sci. 11, 223 (1986)
9) T. -C. Wu, Y. -S. Wang \& Y. -L. Chen: J. Pesticide Sci. (Submitted for publication)

10) M. Ozaki \& S. Kuwatsuka: J. Pesticide Sci. 11, 427 (1986)

11) M. Ozaki \& Y. Hayase: J. Pesticide Sci. 8, 87 (1983)

12) M. Ozaki \& Y. Hayase: J. Pesticide Sci. 6, 447 (1981)

13) D. G. Crosby \& C. S. Tang: J. Agric. Food Chem. 30, 882 (1982)

14) F. S. Tanaka, R. G. Wien \& R. G. Zaylskie: $J$. Agric. Food Chem. 25, 1068 (1977)

\section{要 約}

\section{除草剤イソウロンの水系環境における生分解}

王 一雄, 蔡 顕修, 蘇 永和, 陳 玉麟 除草剂イソウロンの下水拈よび河川水中での生分解を 追った. 下水中ではイソウロンは濃度 0.01 および 0.1 ppm で 120 日間にそれぞれ 31 特よび $25 \%$ が無機化し たが，河川水中では 7\%にとどまった. しかし，後者で はイソウロンは $66 〜 68 \%$ に減少していた.これより， イソウロンは下水中では微生物により主として無機化す るが，河川水中では代謝物（有機）に変わることが推察 された. 7 個の代謝物（らち 2 個は新しい化合物）を同 定して水系環境に㧤けるイソウロンの生分解経路の一部 を明らかにした。 